\title{
Kelola
}

\section{PENGEMBANGAN MODEL PEMBINAAN SEKOLAH IMBAS ADIWIYATA BERBASIS PARTISIPASI}

\author{
Ratih Sulistyowati \\ Magister Manajemen Pendidikan \\ FKIP-Universitas Kristen Satya Wacana \\ ratihsw13@gmail.com \\ Slameto \\ Magister Manajemen Pendidikan \\ FKIP-Universitas Kristen Satya Wacana \\ slameto_uksw@yahoo.com \\ Yari Dwikurnaningsih \\ Magister Manajemen Pendidikan \\ FKIP-Universitas Kristen Satya Wacana \\ yari_bkuksw@yahoo.com
}

\begin{abstract}
The aim of this study is to see the shape of the model of impact school coaching management. This study is Research and Development $(R \& D)$. Data collection use interviewed, documentation, and Focus Group Discussion. The development phase is carried out through: (1) preliminary study, (2) arrangement model, (3) validation by expert from academic and also practitioner, (4) revision of product design and (5) proper model of coaching is tested. Data analysis conducted during in the field with the steps of data reduction, data display, and image/verification conclusions. The results showed that running coaching is difficult to finish. In addition, there is no structured and systematic planning, causing the implementation of coaching run by chance, depend on the demand from the school. There is no evaluation program for the coaching itself. The product of this study is coaching model Adiwiyata school impact base on participation that completed. Based on the feasibility result test conducted by experts and practitioners, the model is considered feasible to be tested by practitioners.
\end{abstract}

Keywords: development, coaching model, impact school, adiwiyata, participation 


\section{PENDAHULUAN}

Program Adiwiyata merupakan program yang dicanangkan oleh pemerintah sejak tahun 2004 dalam rangka mendorong terciptanya pengetahuan dan kesadaran warga sekolah dalam upaya pelestarian lingkungan hidup melalui prinsip edukatif, partisipatif dan berkelanjutan. Program Adiwiyata adalah program yang dibentuk dalam rangka mendorong terciptanya pengetahuan dan kesadaran warga sekolah dalam upaya pelestarian lingkungan hidup. Tujuan program Adiwiyata sendiri sesuai dengan konsepnya adalah mewujudkan warga sekolah yang bertanggung jawab dalam upaya perlindungan dan pengelolaan lingkungan hidup melalui tata kelola sekolah yang baik untuk mendukung pembangunan berkelanjutan (KLH, 2012: 3). Prinsip dasar yang dipegang oleh program Adiwiyata adalah partisipasi, dimana seluruh komponen turut berperan aktif dan berlanjutan, dimana program ini dilakukan secara terus menerus (KLH, 2012: 3).

Dalam pelaksanaan program tersebut, sekolah-sekolah diberi pembinaan agar berhasil menjadi sekolah Adiwiyata. Pembinaan dilakukan oleh Dinas terkait di masing-masing kota hingga dari provinsi. Salah satu penghargaan Adiwiyata yaitu sekolah Adiwiyata Mandiri, merupakan penghargaan kepada sekolah yang telah berhasil mendapatkan penghargaan Adiwiyata tingkat nasional dan memiliki minimal 10 sekolah imbas Adiwiyata, dimana sekolahsekolah imbas tersebut diberi pembinaan oleh calon sekolah Adiwiyata Mandiri dan berhasil menjadi sekolah Adiwiyata.

Berdasarkan hasil wawancara awal yang dilakukan kepada ketua Adiwiyata calon sekolah Adiwiyata Mandiri didapatkan bahwa pembinaan Adiwiyata dilakukan oleh ketua Adiwiyata sekolah dan bersifat monitoring. Tinjauan atau kunjungan ke sekolah-sekolah imbas jarang dilakukan, dan apabila dilakukan hanya jika ada sekolah imbas yang meminta 98 agar pembina datang untuk melihat capaian sekolah imbas itu sendiri. Lebih lanjut dikatakan bahwa hal tersebut terjadi karena adanya kesulitan pembina dalam membagi waktu untuk membina sekolah imbas. Dalam proses pembinaan, pembina merasa kesulitan karena ada beberapa sekolah imbas kurang memiliki motivasi dan antusias, serta komitmen dalam mengikuti program Adiwiyata. Selain itu belum ada pembentukan tim khusus pembinaan, sehingga selama ini yang melakukan pembinaan hanya ketua Adiwiyata. Hal ini juga menjadi kendala karena seluruh tugas dan peran dalam pembinaan dikerjakan oleh pembina. Untuk pelaksanaan pembinaan belum berjalan dengan efektif dan maksimal dikarenakan sekolah imbas belum banyak berpartisipasi secara utuh karena kurang termotivasi dan juga masih memiliki komitmen yang rendah dalam melaksanakan program Adiwiyata ini, padahal keberhasilan untuk mewujudkan harapan seperti tertuang dalam Undang-Undang Nomor 23 Tahun 1997 tentang pengelolaan lingkungan hidup, sesungguhnya membutuhkan partisipasi masyarakat melalui berbagai aktivitas yang dapat dihubungkan dengan pembinaan untuk kepentingan pelestarian lingkungan hidup, sehingga evaluasi yang dilakukan oleh pembina belum dapat mempengaruhi sekolah imbas secara optimal.

Paparan tersebut menunjukkan bahwa model pembinaan Adiwiyata yang ada belum dapat menjawab permasalahan di dalam melaksanakan pembinaan. Pembinaan belum terkonsep dengan baik serta kurangnya partisipasi secara tidak langsung pula memberi dampak negatif baik kepada sekolah induk maupun sekolah imbas dimana program Adiwiyata sulit atau tidak berjalan sebagaimana mestinya dan pada akhirnya tujuan program Adiwiyata sulit untuk tercapai.

Jika merujuk kepada teori mengenai pembinaan sebuah organisasi yang 
dikemukakan oleh Sudjana (2010: 199) pembinaan dapat diartikan sebagai upaya memelihara atau membawa sesuatu keadaan yang seharusnya terjadi atau menjaga sesuatu keadaan sebagaimana seharusnya. Sedangkan Ivancevich (2009: 46) pembinaan adalah sebuah proses sistematis untuk mengubah perilaku kerja seorang/sekelompok pegawai dalam usaha meningkatkan kinerja organisasi. Untuk menghasilkan kinerja pada tingkat yang tinggi, maka seorang manajer atau pemimpin berjuang untuk memotivasi orang-orang di dalamnya dengan melibatkan mereka untuk turut ambil bagian dalam setiap prosesnya, sehingga muncul pertanggungjawaban dalam diri mereka untuk melaksanakan setiap tugas dan tanggungjawab yang diberikan. Sehingga dapat ditarik kesimpulan bahwa untuk melakukan pembinaan harus jelas prosesnya dan harus sistematis, tahapan-tahapannya harus jelas mulai dari perencanaan hingga evaluasinya sehingga pembinaan dapat berjalan dengan efektif. Selain itu pula, motivasi di dalam diri seseorang atau dalam organisasi diperlukan dalam membantu ketercapaian strategi yang telah direncanakan. Motivasi dapat dimunculkan melalui pelibatan secara langsung ke dalam setiap tahapan pembinaan. Dalam hal ini berarti diperlukan sebuah model pembinaan Adiwiyata yang terkonsep mulai dari tahap perencanaan hingga tahap evaluasinya secara kongkret. Selain itu memasukkan basis partisipasi dalam model sangat diperlukan sehingga dapat memotivasi sekolah-sekolah imbas dan dapat memunculkan keberanian dalam diri sekolah imbas untuk menjalin kerja sama dengan pihak atau instansi lainnya. Dengan adanya model pembinaan berbasis partisipasi pula akan diketahui seberapa jauh keefektifan dan keberhasilan pembinaan tersebut dilakukan. Selain itu bila dilihat dari segi waktu akan menjadi lebih efisien serta apabila sewaktuwaktu sekolah imbas dilepas atau dihentikan pembinaannya, mereka dapat berdiri sendiri karena sudah memiliki patokan yang jelas dalam melaksanakan program Adiwiyata.

Yang Ying Ming dkk. (Haryati, 2012:19) menyatakan bahwa model menggambarkan langkah atau prosedur dalam mencapai suatu tujuan, sekaligus dapat digunakan sebagai tolok ukur pencapaian tujuan. Kemudian Richey, dkk (Suparman, 2014: 8) menyatakan bahwa model menggambarkan realitas dengan menampilkan struktur dan tingkatan untuk menyatakan idealisasi dan pandangan tentang suatu realitas. Berdasarkan beberapa pendapat diatas dipahami bahwa istilah model digunakan untuk menjelaskan konsep yang bervariasi karena perlu disesuaikan dengan konteks yang akan digambarkannya serta dapat dikatakan bahwa model memiliki karakteristik: (1) deskriptif naratif; (2) ada prosedur atau langkah; (3) ada tujuan khusus; (4) digunakan untuk mengukur ketercapaian; dan (5) merupakan menggambarkan suatu sistem. Setiap model memiliki tujuan untuk menghasilkan suatu sistem yang efektif dan efisien dalam memfasilitasi pencapaian tujuan. Menurut Marrelli, dkk. (Haryati, 2012: 22), ciri model yang baik adalah: 1) simple, 2) applicable, 3) important, 4) controllable, 5) adaptable, dan 6) communicable. Borg \& Gall (Sugiyono, 2016: 35-36) mengembangkan 10 tahapan dalam mengembangkan model, yaitu: (1) Research and information collecting; (2) Planning; (3) Develop preliminary form of product; (4) Preliminary field testing; (5) Main product revision; (6) Main field testing; (7) Operational product revision; (8) Operational field testing; (9) Final product revision; (10) Dissemination and implementation.

Partisipasi adalah pelibatan seseorang atau beberapa orang dalam suatu kegiatan, baik berupa keterlibatan mental dan emosi serta fisik dalam menggunakan segala kemampuan yang dimilikinya (berinisiatif) dalam segala kegiatan yang dilaksanakan serta mendukung pencapaian tujuan dan 
tanggungjawab atas segala keterlibatan (Astuti, 2009: 31-32). Berkenaan dengan pembinaan Adiwiyata kepada sekolah imbas berbasis partisipasi, maka pembinaan adalah upaya untuk membawa dan memelihara atau menjaga agar sekolah imbas dapat menjadi sekolah Adiwiyata maupun mempertahankan sebagai sekolah Adiwiyata. Pelaksanaan pembinaan ditujukan agar kegiatan atau program yang sedang dijalankan yang dalam hal ini adalah program Adiwiyata selalu sesuai dengan rencana atau tidak menyimpang dari rencana yang telah ditetapkan yaitu sekolah imbas dapat menjadi sekolah Adiwiyata. Jika terjadi penyimpangan, segera dapat dilakukan upaya untuk mengembalikan kegiatan pada yang seharusnya dilakukan. Dalam setiap tahap pembinaan dimasukkan unsur partisipasi dari peserta pembinaannya, mulai dari materi pembinaan, bentuk pembinaan, pengambilan keputusan dalam pembinaan, pelaksanaan pembinaan, hingga bentuk evaluasinya. Sehingga setiap orang yang terlibat dalam pembinaan termotivasi dan melakukan tugasnya secara bertanggungjawab. Keberhasilan pembinaan berbasis partisipasi disebabkan karena adanya pembinaan yang berdasarkan kebutuhan tiap peserta pembinaan, yaitu keinginan atau kehendak yang dirasakan oleh peserta pembinaan, baik berupa pengetahuan, keterampilan, dan sikap, kemudian adanya pembinaan yang berorientasi kepada tujuan yang telah disepakati bersama, adanya pembinaan yang berpusat kepada peserta pembinaan, dimana kegiatan pembinaan bertolak dari kondisi setiap peserta pembinaan, seperti kondisi ekonomi, lingkungan, sarana pendukung, dan lainnya, serta adanya pembinaan yang berdasarkan pada pengalaman masing-masing peserta, dimana kegiatan pembinaan mengacu pada pengalaman-pengalaman yang dimiliki oleh setiap peserta pembinaan, berupa pengetahuan, keterampilan, dan sikap.

\section{METODE PENELITIAN}

Penelitian dilakukan di salah satu sekolah swasta yang sedang mengikuti program Adiwiyata Mandiri di Salatiga pada Oktober 2016 sampai Mei 2017. Penelitian ini dirancang melalui pendekatan Research and Development $(R n D)$ yang didalamnya terdapat dua kegiatan yaitu meneliti lalu hasil penelitian tersebut dikembangkan guna memperbaiki program yang sudah ada sebelumnya. Produk yang dihasilkan dalam penelitian ini dikembangkan melalui langkahlangkah pengembangan oleh Borg and Gall (Sugiyono, 2016: 35-36) sehingga dihasilkan sebuah model pembinaan bagi sekolah imbas Adiwiyata. Namun pada penelitian ini dibatasi hingga pada tahap yang kelima yaitu hingga menghasilkan model yang telah divalidasi oleh ahli dan layak untuk diujicobakan. Berdasarkan langkah-langkah pengembangan Borg dan Gall, kemudian disusun kembali langkah-langkah pengembangan model pembinaan sebagai berikut:

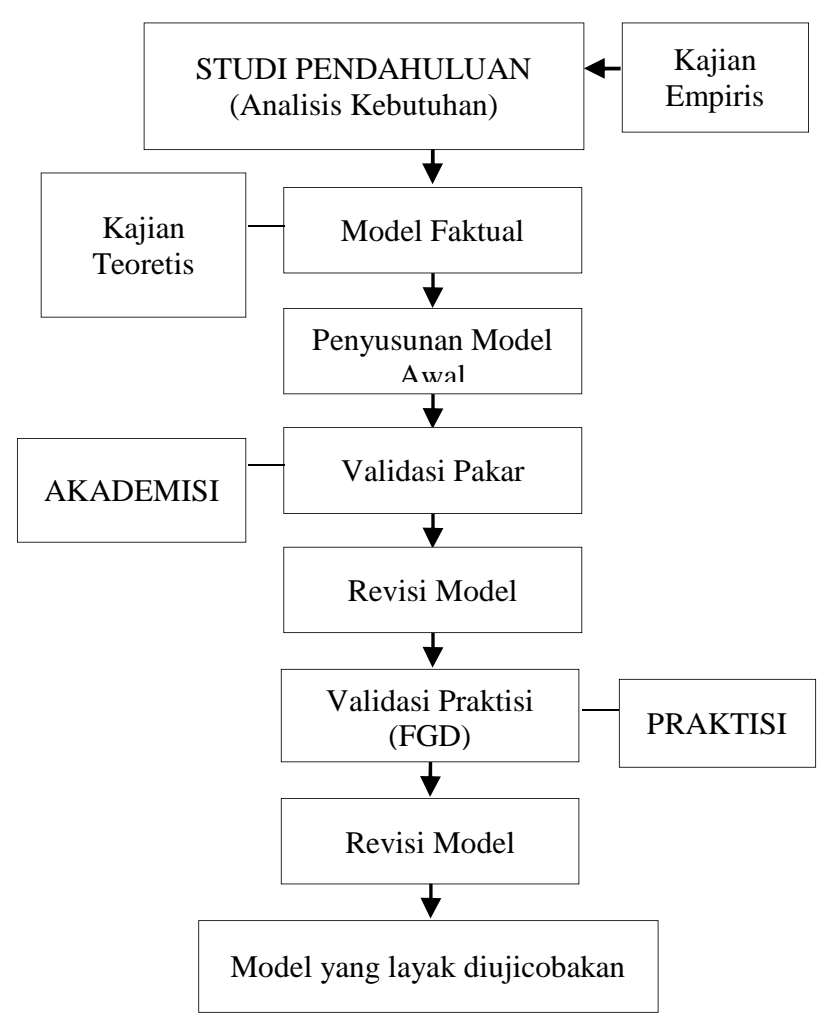

Gambar 1 Alur Penelitian Reseacrh and Development Model Pembinaan 
Data diperoleh melalui wawancara dengan beberapa narasumber terkait, studi dokumentasi, dan FGD. Aktivitas dalam analisis data baik sebelum dilapangan maupun selama di lapangan, yaitu data reduction, data display, dan conclusion drawing/verivication. Reduksi data digunakan untuk memilah data, dalam artian berarti merangkum, memilih halhal pokok, menfokuskan pada hal-hal yang penting, dicari tema dan polanya. Dengan demikian data yang telah direduksi akan memberikan gambaran yang lebih jelas, dan mempermudah peneliti untuk mengumpulkan data selanjutnya, dan mencarinya bila diperlukan. Data yang telah direduksi kemudian disajikan sedemikian rupa dalam bentuk uraian singkat dan bagan yang padu sehingga akan memudahkan untuk memahami apa yang terjadi, merencanakan kerja selanjutnya berdasarkan apa yang telah dipahami tersebut. Data yang telah disajikan secara padu akan menghasilkan sebuah kesimpulan, baik yang bersifat sementara maupun yang akan berubah seiring banyaknya temuan yang akan didapatkan peneliti.

Teknik validasi data menggunakan uji kredibilitas atau kepercayaan terhadap data (validasi internal). Pengujian data yang diperoleh dilakukan sebelum dilapangan dan selama dilapangan dengan menggunakan teknik triangulasi yang diartikan sebagai pengecekan data dari berbagai sumber dengan berbagai cara, dan berbagai waktu. Dalam hal ini digunakan teknik triangulasi sumber yaitu membandingkan hasil wawancara yang didapatkan dari beberapa narassumber terkait untuk melihat kebenaran data.

\section{HASIL DAN PEMBAHASAN}

Berdasarkan temuan-temuan pada studi pendahuluan mengenai model faktual pembinaan yang selama ini digunakan tertuang dalam gambar berikut.

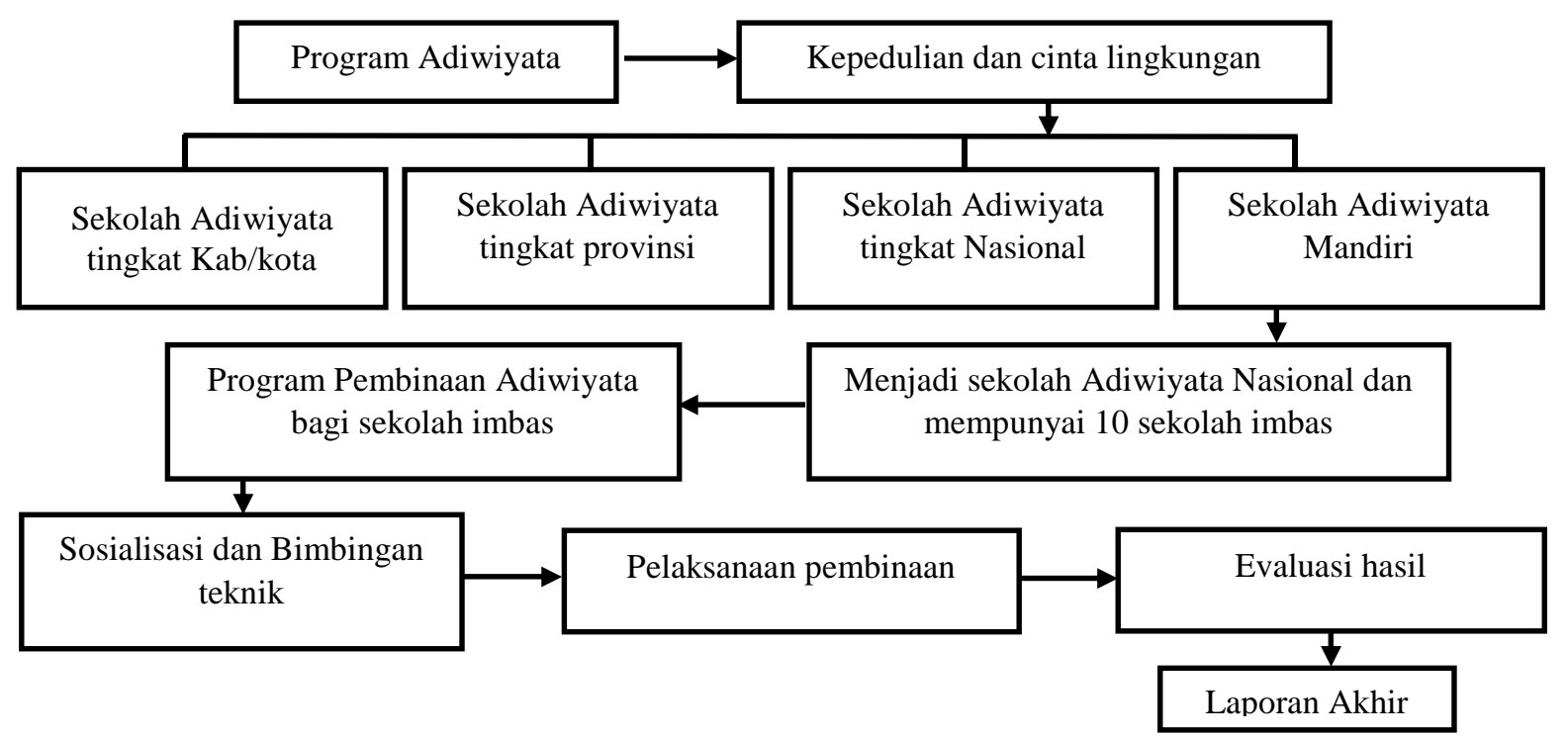

Gambar 2 Model Faktual Pembinaan Sekolah Imbas Adiwiyata

Berdasarkan gambar 2 dapat dijelaskan bahwa penyelenggaraan pembinaan sekolah imbas Adiwiyata yang selama ini dilaksanakan adalah sebagai berikut. Program Adiwiyata merupakan program yang dibuat dengan tujuan untuk membentuk rasa kepedulian dan cinta lingkungan dari masyarakat, yang dimulai dari lingkungan sekolah. Program ini memiliki empat jenis penghargaan yang bertahap, mulai dari tingkat kabupaten/kota, provinsi, nasional, dan pada akhirnya menjadi sekolah Adiwiyata Mandiri, dimana syarat untuk menjadi sekolah Adiwiyata Mandiri adalah sekolah tersebut sudah mencapai penghargaan Adiwiyata tingkat nasional serta memiliki minimal 10 sekolah binaan sebagai 
imbas Adiwiyata. Dalam program pembinaan, sebelum pembinaan dilaksanakan dilakukan sosialisasi dan bimbingan teknik kepada sekolah-sekolah imbas mengenai pengenalan program Adiwiyata, administrasinya, serta bagaimana penerapannya di sekolah, setelah itu baru pembinaan dilaksanakan.

Selama melaksanakan pembinaan, calon sekolah Adiwiyata Mandiri atau disebut sekolah induk mengalami kesulitan. Keefektifan pembinaan Adiwiyata yang dilakukan oleh sekolah masih rendah yang ditunjukkan dengan belum adanya perencanaan khusus untuk pembinaan itu sendiri karena mengingat adanya beberapa pertimbangan terutama waktu, sehingga pembinaan bisa dilakukan ketika ada waktu kosong dan juga harus menyesuaikan dengan waktu yang dimiliki oleh sekolah imbas itu sendiri, sehingga dalam hal ini dapat dikatakan bahwa pembinaan masih bersifat insidental. Selain itu pula adanya perubahan rencana karena antara pihak sekolah imbas dan sekolah induk sering berbenturan jadwalnya dengan kegiatan dinas lainnya. Dalam pengorganisasiannya sendiri belum ada pembentukan tim khusus pembinaan, sehingga selama ini yang melakukan pembinaan hanya ketua Adiwiyata. Hal ini juga menjadi kendala karena dengan begitu seluruh tugas dan peran yang seharusnya tidak dikerjakan oleh pembina, maka kemudian dikerjakan oleh pembina. Untuk pelaksanaan pembinaan belum berjalan dengan efektif dan maksimal dikarenakan sekolah imbas belum banyak berpartisipasi secara utuh karena kurang termotivasi dan juga masih memiliki komitmen yang rendah dalam melaksanakan program Adiwiyata ini, padahal keberhasilan untuk mewujudkan harapan seperti tertuang dalam Undang-Undang Nomor 23 Tahun 1997 tentang pengelolaan lingkungan hidup, sesungguhnya membutuhkan partisipasi masyarakat melalui berbagai aktivitas yang dapat dihubungkan dengan pembinaan untuk kepentingan pelestarian lingkungan hidup, sehingga evaluasi yang dilakukan oleh pembina belum dapat mempengaruhi sekolah imbas secara optimal.

\section{Hasil Pengembangan}

Model pembinaan sekolah imbas Adiwiyata berbasis partisipasi dikembangkan berdasarkan hasil studi pendahuluan mengenai analisis terhadap model faktual dalam pembinaan. Pengembangan ini juga didasarkan pada hasil kajian teoretis terhadap manajemen dalam pembinaan. Pengembangan model dilaksanakan dengan tahap-tahap: identifikasi kebutuhan dalam pembinaan yang didapat melalui analisis model faktual dalam pelaksanaan pembinaan selama ini, (2) penyusunan program pembinaan, (3) validasi isi oleh pakar dalam bidang manajemen, pakar Adiwiyata, serta praktisi pembinaan.

$\begin{array}{ccc} & \text { Penyusunan model pembinaan yang } \\ \text { telah dikembangkan meliputi: }\end{array}$ pendahuluan, dimana didalamnya berisi latar belakang, dasar hukum, tujuan, manfaat model, dan spesifikasi model; (2) kajian teori mengenai pembinaan berbasis partisipasi; (3) persyaratan pokok model; (4) deskrispi model yang meliputi, gambar model, rasional model, materi pembinaan, serta deskripsi tahap perencanaan, pengorganisasian, pelaksanaan, dan evaluasi. Pada perencanaan meliputi identifikasi kebutuhan pembinaan, perumusan tujuan pembinaan, mengembangkan struktur program pembinaan, rencana pelaksanaan pembinaan, materi pembinaan, mengembangkan buku panduan pembinaan untuk pembina dan peserta pembinaan, panduan monitoring dan evaluasi pembinaan, serta merencanakan waktu pembinaan. Dalam pengorganisasian pembinaan meliputi pengorganisasian sumber daya manusia, dimana didalamnya disusun struktur kepengurusan pembinaan, jabaran tugas masing-masing, persyaratan personil, serta mekanisme kerja dalam kepengurusan 
pembinaan. Sedangkan pada pada pelaksanaan pembinaan terdiri dari sosialisasi pengenalan Adiwiyata, tujuan, pengenalan dari segi administrasi Adiwiyata, dan bimbingan teknik pelaksanaan Adiwiyata serta pembinaan Adiwiyata. Setelah itu pelaksanaaan pembinaan itu sendiri, dimana didalamnya ada kegiatan monitoring dan evaluasi, serta rencana tindak lanjut. Pada bagian evaluasi meliputi evaluasi peserta pembinaan, pembina, dan evaluasi program pembinaan. Berikut adalah gambar desain model pembinaan.

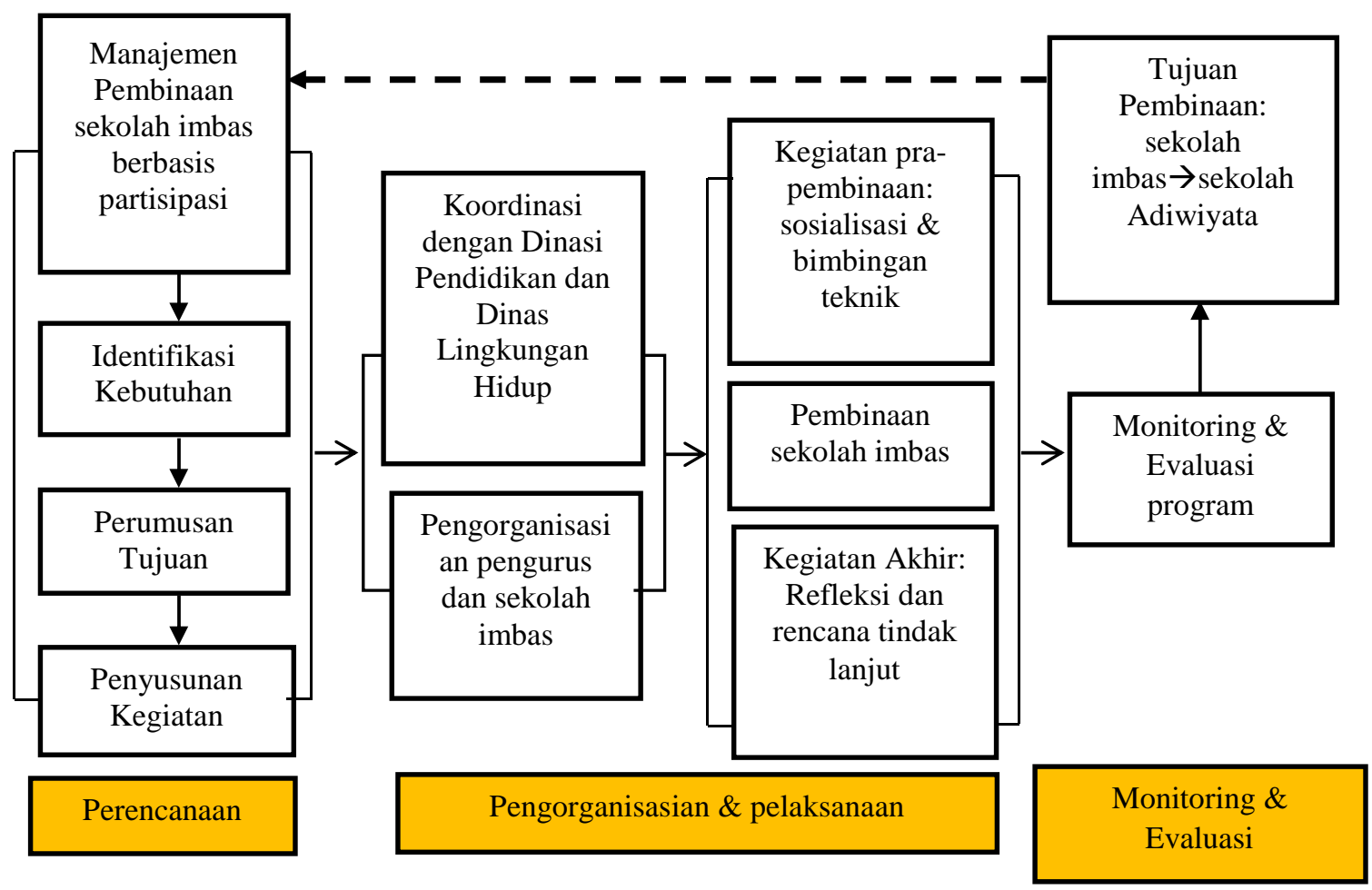

Gambar 3 Desain Model Pembinaan Sekolah Imbas Adiwiyata

Setelah dibuat perancangan desain model pembinaan sekolah imbas Adiwiyata berbasis partisipasi kemudian dilakukan validasi oleh ahli secara teoretis terhadap desain model tersebut. Validasi model oleh ahli dilakukan dengan tujuan untuk mendapatkan masukan tentang kelemahankelemahan model dipandang dari segi teotiris oleh para ahli. Kelemahan-kelemahan tersebut kemudian diusahakan untuk dikurangi atau diperbaiki melalui revisi desain.

Validasi model dilakukan melalui uji pakar, yaitu 1 (satu) pakar dalam bidang manajemen, 1 (satu) pakar dalam bidang Adiwiyata, dan 1 (satu) pakar dalam bidang khusus pembinaan Adiwiyata. Validasi model dilakukan dengan menggunakan instrumen berupa angket yang disertai dengan kolom cacatan atau komentar tambahan yang dapat diberikan oleh para ahli.

Untuk mengetahui rentang tingkat kelayakan model dapat digunakan rumus:

Sehingga: $\frac{\varepsilon \quad t_{1}}{a} \quad-s \quad t \quad n=\frac{a-1}{3}=1$

Sehingga rentang nilai kelayakan dapat diketahui sebagai berikut ini:

$\begin{array}{ll}\text { Tidak Layak } & =0,0-1,0 \\ \text { Cukup Layak } & =1,1-2,0 \\ \text { Layak } & =2,1-3,0 \\ \text { Sangat Layak } & =3,1-4,0\end{array}$

Berdasarkan hasil analisis data validasi ahli diperoleh rerata 2,7, sehingga untuk setiap komponen model dapat dikatakan layak untuk diujicobakan.

Desain model yang telah diberi penilaian oleh pakar dan telah di revisi 
kemudian di uji kelayakannya. Uji kelayakan dilakukan melalui Focus Group Discussion (FGD) dengan menghadirkan praktisi-praktisi dalam bidang pembinaan Adiwiyata, baik penyelenggara atau dari sekolah induk, maupun peserta atau dalam hal ini adalah sekolah imbas, sebagai sekolah yang dibina. Dalam hal ini selain dilakukan diskusi, diberikan juga angket yang disertai dengan kolom cacatan atau komentar tambahan yang dapat diberikan oleh para praktisi. Berdasarkan hasil analisis data validasi ahli diperoleh rerata 3,4, sehingga untuk setiap komponen model dapat dikatakan sangat layak untuk diujicobakan.

Berikut adalah tabel perbandingan untuk melihat pengembangan model pada setiap tahapan pengembangan.

Tabel 1 Hasil Pengembangan Model Pada setiap Tahapan Pengembangan

\begin{tabular}{|c|c|c|c|c|c|}
\hline No & Aspelk & Model Falctual & $\begin{array}{c}\text { Desain Pengembangan } \\
\text { Model Awal }\end{array}$ & $\begin{array}{l}\text { Model Hasil Validasi } \\
\text { Palcar } \\
\end{array}$ & Model Hasil Uji Kelayalaan \\
\hline \multirow[t]{2}{*}{1} & Gambar Model & $\begin{array}{l}\text { Tidak terdapat rincien } \\
\text { kegiztan yang jelas pada } \\
\text { tiap tahapan kegiatan }\end{array}$ & $\begin{array}{l}\text { Terdapat siklus dengen } \\
\text { rincien kegiatan yang jelas } \\
\text { pada tiep tahzpan kegiztan }\end{array}$ & $\begin{array}{l}\text { Terdapat siklus dengen } \\
\text { rincian kegiztan yang } \\
\text { jelas pada tizp tahypan } \\
\text { kegiztan }\end{array}$ & $\begin{array}{l}\text { Terdapat siklus dengan rincian } \\
\text { kegiatan yangjelas padatizp tahapan } \\
\text { kejatan }\end{array}$ \\
\hline & & $\begin{array}{l}\text { Tidak ada kolom tindak } \\
\text { lenjut }\end{array}$ & Ada kolom tindak lanjut & Ada kolomtindaklanjut & Ada kolom tindak lanjut \\
\hline \multirow[t]{2}{*}{2} & Perencanaan & $\begin{array}{l}\text { Tidak adakegiatan analisis } \\
\text { kebutuhan pembinazn, } \\
\text { perumusan tujuan, dan } \\
\text { penyusunm kegiatan } \\
\text { pembinan. }\end{array}$ & $\begin{array}{l}\text { Ada kegiztan unalisis } \\
\text { kebutuhan pembinazn, } \\
\text { perumusan tujuan, dan } \\
\text { penyusunan kegatm } \\
\text { pembinazn. }\end{array}$ & $\begin{array}{l}\text { Ada kegiatan analisis } \\
\text { kebutuhan pembinzan, } \\
\text { perumusan tujuzm, dan } \\
\text { penyusunem kegiztan } \\
\text { pembinam. }\end{array}$ & $\begin{array}{l}\text { Ada kegiztan analisis kebutuhan } \\
\text { pembinazn, perumusan tujuzn, dan } \\
\text { penyusunan kegiatan pembinzan }\end{array}$ \\
\hline & & $\begin{array}{l}\text { Tidak terdapat buku } \\
\text { pegangen bagi Pembina, } \\
\text { gekolah imbas, den untuk: } \\
\text { kegiztan monitoring dan } \\
\text { evaluasi }\end{array}$ & $\begin{array}{l}\text { Terdapat buku pegangen } \\
\text { bagi Pembina, sekolah } \\
\text { imbas, dan untuk kegiztan } \\
\text { monitoring dan evaluasi } \\
\text { namun kurang operasional } \\
\text { dan masih terlalu teoretis }\end{array}$ & $\begin{array}{l}\text { Terdapat boku pegangan } \\
\text { bagi Pembina, gekolah } \\
\text { imbas, dan untuk } \\
\text { kegiatan monitoring dan } \\
\text { evaluasi numun kurang } \\
\text { operasional dan masih } \\
\text { terlalu teoretis. }\end{array}$ & $\begin{array}{l}\text { Buku panduen lebih } \\
\text { dioperasionalkan }\end{array}$ \\
\hline 3 & Pengorganisasizn & $\begin{array}{l}\text { Belum ada pembentukan } \\
\text { pengurus pembinzan }\end{array}$ & $\begin{array}{l}\text { Adz pembentukan } \\
\text { pengurus pembinan } \\
\text { beserta dengn syarat dan } \\
\text { tugas masing-musing } \\
\text { personil }\end{array}$ & $\begin{array}{l}\text { Ada pembentukan } \\
\text { pengurus pembinzan } \\
\text { beserta dengen syarat } \\
\text { dantuggs masing-masing } \\
\text { personil }\end{array}$ & $\begin{array}{l}\text { Ada pembentukan pengurus } \\
\text { pembinzan beserta dengan syurat } \\
\text { dan tugas masing-mzsing personil }\end{array}$ \\
\hline 4 & Pelaksanzan & $\begin{array}{l}\text { Tidak adz tahzpan dalam } \\
\text { pelaksanzm }\end{array}$ & $\begin{array}{l}\text { Adz tahzpan dalam } \\
\text { pelaksanam, yaitu tahap } \\
\text { persizpan, pra-pembinzan, } \\
\text { pembinzan, dan kegiatan } \\
\text { akhir }\end{array}$ & $\begin{array}{l}\text { Ada tahzpan dalam } \\
\text { pelaksanam, yaitutahap } \\
\text { persizpan, pre- } \\
\text { pembinzan, pembinazn, } \\
\text { dan kegiatan akhir }\end{array}$ & $\begin{array}{l}\text { Ada tahapan dalam pelaksanzan, } \\
\text { yaitu thhap persizpan, pra- } \\
\text { pembinaan, pembinzan, dan } \\
\text { kegiatan akhir }\end{array}$ \\
\hline 5 & $\begin{array}{l}\text { Monitoring dan } \\
\text { Evaluagi }\end{array}$ & $\begin{array}{l}\text { Belum ada dilakukan } \\
\text { evaluzsiprogram }\end{array}$ & $\begin{array}{l}\text { Dilakukan evaluasi } \\
\text { program }\end{array}$ & $\begin{array}{l}\text { Dilakukan evaluasi } \\
\text { program }\end{array}$ & Dilakukan evaluasi program \\
\hline
\end{tabular}

\section{Pembahasan}

Model pembinaan sekolah imbas Adiwiyata dikembangkan dengan berbasis partisipasi dengan harapan dapat mengatasi kelemahan-kelemahan yang ada pada model pembinaan yang dilaksanakan sebelumnya. Bertolak dari adanya hambatan-hambatan tersebut, maka diperlukan pengembangan model pembinaan yang dapat mengatasi masalah atau hambatan tersebut.

$$
\text { Pengembangan model dilakukan }
$$
dengan merujuk kepada 4 komponen manajemen, yaitu perencanaan, pengorganisasian, pelaksanaan, dan monitoring dan evaluasi, dimana dalam setiap komponen dimasukkan konsep partisipasi, 
yaitu partisipasi dari sekolah imbas agar sekolah imbas turut bertanggungjawab dalam pelaksanaan pembinaan. Gagasan ini didukung oleh penelitian yang dilakukan oleh Karim (2012: 56) mengenai "Manajemen Pendidikan Lingkungan Hidup Berbasis Partisipasi" yang menyatakan bahwa partisipasi dapat memberikan kontribusi untuk mengisi dan mengatasi berbagai permasalahan lingkungan. Bentuk-bentuk partisipasi bisa mulai dari spektrum yang paling ekstrim sampai pada bentuk kemitraan. Melalui partisipasi yang aktif, mereka dapat mengeksplorasikan kepeduliaannya maupun melakukan kontrol. Hal ini juga sejalan dengan penelitian yang dilakukan Bandiyah (2016: 12) tentang "Pelatihan dan Pendampingan Penyusunan Rencana Penyusunan Jangka Menengah (RPJM) Desa Berbasis Partisipatif di Desa Lokasari, Sidemen, Karangasem, Bali” yang mengatakan bahwa hasil sebuah perencanaan dapat diterima dengan baik oleh masyarakat setempat apabila dalam penyusunannya melibatkan partisipasi dari masyarakat. Tanpa partisipasi, biasanya hasil perencanaan berakibat pada kekecewaan karena tidak sesuai dengan keinginan dan harapan dari masyarakat. Di samping itu, akan sulit mengharapkan masyarakat untuk mematuhi dan menjaga pelaksanaan kegiatan yang telah dibuat sebelumnya.

Penelitian lainnya dilakukan oleh Wiyono, dkk (2014: 170) tentang "Grand Design Model Pembinaan Profesional Guru Berbasis Determinan Kinerja Guru" yang dalam mengembangkan model pembinaan bagi guru juga menemukan hambatan yang sama seperti yang ditemukan oleh peneliti dalam rangka pengembangan model pembinaan ini, yakni dimana hambatan yang paling dominan adalah kurangnya waktu dan banyaknya tugas atau pekerjaan lainnya yang harus dilakukan. Hal ini serupa dengan yang ditemukan oleh peneliti, dimana salah satu kendala terhambatnya pelaksanaan pembinaan kepada sekolah imbas ini adalah waktu pembinaan yang tidak terstruktur karena kesibukan masing-masing, baik dari pihak sekolah induk, maupun sekolah imbas. Lebih lanjut Wiyono (2016: 170) menyarankan langkah yang ditempuh dalam mengatasi hambatan tersebut adalah mengatur jadwal kegiatan dengan sebaik-baiknya, mengatur waktu secara efisien, mencari informasi melalui berbagai sumber (teknologi, teman, atau sumber lainnya), memanfaatkan fasilitas yang ada secara optimal, mengembangkan diri secara mandiri, menindaklanjuti hasil pembinaan, mengadakan forum pembinaan mandiri, menambah jam pelajaran, mengadakan pembinaan secara pribadi, menyusun program pembinaan, meningkatkan kerjasama, dan mengadakan pembinaan secara berkelanjutan. Hasil penelitian tersebut kemudian menjadi acuan bagi peneliti sehingga perlu mengembangkan model pembinaan sekolah imbas Adiwiyata ini. Dengan desain manajemen program yang jelas, segala kebutuhan yang berhubungan dengan pembinaan sekolah imbas Adiwiyata, akan memberikan kejelasan tentang model pembinaan sekolah imbas Adiwiyata mulai dari perencanaan, tujuan, materi pembinaan, strategi pembinaan, dan evaluasi hasil yang diperoleh.

Penelitian lainnya yang dilakukan oleh Dewi (2013: 135) tentang "Pengembangan desa wisata berbasis partisipasi Masyarakat lokal di desa wisata Jatiluwih Tabanan, Bali" mengatakan bahwa parameter yang digunakan untuk menentukan derajat partisipasi masyarakat dalam tahap perencanaan adalah keterlibatan dalam identifikasi masalah, perumusan tujuan, dan pengambilan keputusan terkait. Dalam hal ini, temuan penelitian Dewi kemudian menjadi acuan dalam perencanaan kegiatan pembinaan yang dikembangkan.

Dari beberapa paparan penelitian di atas dapat diketahui basis partisipasi yang dipilih merupakan langkah yang tepat untuk 
mengatasi kendala yang ada selama proses pembinaan yang selama ini berlangsung, dimana dengan menerapkan konsep partisipasi maka untuk jadwal pembinaan dapat ditentukan secara bersama pada awal perencanaan, sehingga apabila ada kegiatan dinas lainnya, maka dapat dengan cepat dicarikan solusi bersama untuk pelaksanaan waktu pembinaan. Kemudian, dengan adanya konsep partisipasi yang melibatkan sekolah imbas pada seluruh tahapan manajemen pembinaannya akan memberikan respon positif dari sekolah imbas agar lebih bertanggungjawab dalam pelaksanaan program, dan memunculkan motivasi serta komitmen dari skeolah imbas itu sendiri. Dengan selalu menjaga komitmen tersebut, maka rotasi kepala sekolah kemudian tidak menjadi halangan putusnya rantai Adiwiyata dalam pembinaan tersebut.

Dalam pengimplementasian model pembinaan sekolah imbas Adiwiyata berbasis partisipasi, maka empat komponen manajemen yang ada dalam model, yaitu perencanaan, pengorganisasian, pelaksanaan, serta monitoring dan evaluasi dilaksanakan dengan melibatkan sekolah imbas dengan harapan bahwa nantinya pembinaan dapat berjalan dengan efisien karena sesuai dengan kebutuhan dan kemampuan masing-masing sekolah imbas dan juga sekolah imbas dapat termotivasi untuk melaksanakan program Adiwiyata disekolah masing-masing. Dalam perencanaan sekolah imbas berpartisipasi dengan sekolah induk dalam menentukan kebutuhan dan kemampuan serta keadaan lingkungan masing-masing sekolah imbas dalam rangka mewujudkan program Adiwiyata, dimana hal tersebut kemudian menjadi dasar dalam menentukan tujuan pembinaan dan materi pembinaan serta bentuk pelaksanaan pembinaan.

Dalam pengorganisasian, sekolah imbas berpartisipasi dalam keanggotaan pengurus pembinaan, sehingga, dapat memudahkan dalam mengatur waktu dan tempat pembinaan, selain itu pula, apabila sekolh imbas mengalami kesulitan dalamm pelaksanaan Adiwiyata disekolahnya, maka dapat secara langsung mendiskusikan dengan anggota pengurus lainnya, sehingga masalah tersebut dapat secara langsung teratasi.

Dalam pelaksanaan, sekolah imbas berpartisipasi dalam mengikuti kegiatan pembinaan secara utuh dan pelaksanaan pembinaan dilaksanakan sesuai dengan jadwal dan tempat yang telah ditentukan bersama sekolah imbas dan sekolah induk. Sedangkan dalam kegiatan monitoring dan evaluasi, sekolah induk dan sekolah imbas turut berpartisipasi dalam memonitoring jalannya pembinaan, pelaksanaan program Adiwiyata disekolah masing-masing sekolah imbas, dan juga bersama dengan sekolah induk mengevaluasi proses pembinaan, hasil pembinaan, serta program pembinaan yang telah dilaksanakan sehingga didapatkan kesimpulan bersama untuk mengetahui keberhasilan program pembinaan yang telah dilaksanakan, kekurangan yang ditemukan selama pelaksanaan program sehingga dapat menjadi saran untuk memperbaiki program pembinaan tersebut kedepannya.

Kelebihan model pembinaan sekolah imbas Adiwiyata yang dikembangkan ini adalah: (1) adanya analisis kebutuhan pembinaan, rumusan tujuan, dan penentuan materi pembinaan yang dibuat bersama dengan sekolah imbas, sehingga pembinaan akan terlaksana sesuai dengan kebutuhan masingmasing sekolah imbas untuk memenuhi adanya keragaman masing-masing sekolah imbas; (2) model dikembangkan menjadi 4 komponen manajemen, yaitu perencanaan, pengorganisasian, pelaksanaan, dan monitoring dan evaluasi; (3) model dikembangkan berbasis kepada partisipasi; (4) pada aspek perencanaan dilakukan perencanaan yang sistematis, mengacu kepada kebutuhan sekolah imbas; (5) pada aspek 
pengorganisasian dirincikan tugas dan prasyarat masing-masing pihak yang terlibat dalam pembinaan; (6) pada aspek pelaksanaan pembinaan dijabarkan kembali menjadi 4 kegiatan, yaitu kegiatan persiapan, prapembinaan, pelaksanaan, dan kegiatan akhir. Selain itu pula untuk waktu pembinaan dibuat berdasarkan kesepakatan sekolah induk dan sekolah imbas di awal sebelum pembinaan dilaksanakan; (7) pada aspek monitoring dan evaluasi dilakukan monitoring oleh sekolah induk maupun oleh sekolah imbas terhadap seluruh rangkaian kegiatan pembinaan. Selain itu pula dilakukan evaluasi oleh sekolah induk dan sekolah imbas untuk keseluruhan komponen manajemen pembinaan, evaluasi proses, dan evaluasi hasil; (8) selama ini belum pernah ada dilakukan penelitian mengenai pengembangan model pembinaan sekolah imbas Adiwiyata.

Adapun kekurangan model ini adalah: (1) pada dasarnya sudah ada penelitian terdahulu dengan basic atau dasar yang sama mengenai Adiwiyata, namun untuk penelitian yang lebih spesifik terutama mengenai pembinaan sekolah imbas Adiwiyata belum ditemukan, sehingga pengembangan model hanya didasarkan pada teori-teori yang ada, bukan berdasarkan pada kekurangan temuan penelitian terdahulu; (2) perlu dilakukan ujicoba baik ujicoba skala terbatas, maupun secara luas terhadap model untuk melihat keefektivitasan model dalam pembinaan.

\section{Implikasi Hasil Penelitian}

Implikasi dari hasil penelitian ini meliputi: (1) secara teoretis, hasil penelitian ini memberikan implikasi terhadap pengembangan model pembinaan sekolah imbas Adiwiyata berbasis partisipasi, dimana model dikembangkan dalam 4 komponen manajemen, sehingga kegiatan pembinaan memiliki tujuan dan arah yang jelas serta dapat dijalankan lebih efisien; (2) secara teoretis, hasil penelitian ini memberikan implikasi terhadap pengembangan model pembinaan sekolah imbas Adiwiyata berbasis partisipasi, dimana partisipasi yang dilibatkan dalam pembinaan memberikan kontribusi sangat besar dalam pelaksaaan pembinaan sehingga bisa lebih efisien; (3) penerapan model pembinaan sekolah imbas Adiwiyata berbasis partisipasi menuntut baik Pembina maupun sekolah imbas untuk bertanggungjawab dan berkomitmen atas keseluruhan tahapan pembinaan, sehingga pembinaan dapat berhasil dan kedua pihaks aling diuntungkan; (4) penerapan model pembinaan sekolah imbas Adiwiyata berbasis partisipasi berimplikasi pada upaya peningkatan capaian sekolah imbas dalam mengikuti program Adiwiyata. Selain itu pula, berimplikasi pada upaya peningkatan partisipasi sekolah imbas dalam program Adiwiyata.

\section{SIMPULAN DAN SARAN}

\section{Simpulan}

Model pembinaan sekolah imbas Adiwiyata yang selama ini dijalankan belum baik. Hal ini ditunjukkan dengan: (1) belum adanya perencanaan pembinaan yang disusun dengan matang, (2) tidak ada analisis kebutuhan yang mendasari kegiatan pembinaan, (3) tidak ada rumusan tujuan pembinaan yang dibuat, (4) belum pernah dilakukan evaluasi program pembinaan.

Berdasarkan hal tersebut, maka kemudian disusun desain model pembinaan sekolah imbas Adiwiyata berbasis partisipasi yang layak diterapkan, meliputi: perencanaan pembinaan yang terdiri dari 3 kegiatan utama, yaitu: analisis kebutuhan, perumusan tujuan, penyusunan materi pembinaan, kemudian pemaparan tujuan, manfaat, dan materi pembinaan Adiwiyata secara umum, mengembangkan materi berbasis partisipasi, media dan perangkat evaluasi, mengembangkan buku panduan bagi pembina, sekolah imbas, dan panduan monitoring dan evaluasi, merencanakan 
konsep pelaksanaan; (2) pengorganisasian struktur pengurus pembinaan, syarat personil dan tugas personil yang terlibat dalam pembinaan (3) pelaksanaan pembinaan terdiri dari: kegiatan persiapan, pra-pembinaan, pelaksanaan pembinaan, dan kegiatan akhir (4) evaluasi pembinaan yang terdiri dari: evaluasi proses, evaluasi hasil, evaluasi program, evaluasi sekolah imbas, dan evaluasi sekolah induk/pembina. Model pembinaan sekolah imbas Adiwiyata berbasis partisipasi adalah model yang didapatkan setelah dilakukan uji kelayakan oleh ahli secara teoretis dan ahli implementasi atau praktisi dilapangan. Hasil ujicoba kelayakan menunjukkan bahwa model layak untuk diujicobakan.

\section{Saran}

Saran disampaikan kepada pihak yang terlibat dalam pelaksanaan pembinaan, yaitu Pembina dari sekolah induk, sekolah imbas, dan peneliti selanjutnya. Bagi sekolah induk, dalam mengembangkan pembinaan hendaknya: (1) membuat perencanaan pembinaan yang berdasarkan dengan kebutuhan sekolah imbas, (2) melakukan monitoring selama kegiatan pembinaan secara rutin, (3) mengadakan evaluasi terhadap program pembinaan, (4) mengembangkan pembinan sekolah imbas Adiwiyata berbasis partisipasi agar dapat menjangkau pembinaan lebih luas lagi. Bagi sekolah imbas hendaknya memotivasi diri serta tetap menjaga komitmen untuk senantiasa mengembangkan diri sehingga berhasil menjadi sekolah Adiwiyata. Bagi peneliti selanjutnya, untuk mengetahui efektivitas model yang dikembangkan ini, maka perlu dilakukan pengembangan tahapan selanjutnya baik ujicoba terbatas, maupun diperluas.

Adapun keterbatasan dalam penelitian ini adalah pengembangan model pembinaan sekolah imbas Adiwiyata berbasis partisipasi ini di fokuskan kepada sistem manajemen pembinaannya yang dapat berjalan dengan baik asal seluruh pihak yang terlibat bertanggungjawab dan juga mengikuti runtutan langkah dalam manajemen ini. Capaian pengembangan model ini masih perlu dikembangkan melalui tahap penelitian selanjutnya, ujicoba terbatas dan ujicoba yang lebih luas. Selain itu subyek ujicoba model ini hanya dilakukan pada satu sekolah calon Adiwiyata mandiri yang ada di Salatiga, sehingga belum dapat menjamin bahwa model ini dapat memecahkan semua kendala yang ada dalam pembinaan sekolah imbas Adiwiyata.

\section{DAFTAR PUSTAKA}

Astuti, D. 2009. Desentralisasi dan Partisipasi Dalam Pendidikan. Yogyakarta: UNY

Bandiyah. 2016. Pelatihan dan Pendampingan Penyusunan RPJMDesa Berbasis Partisipasi di Desa Lokasari, Sidemen, Karangasem, Bali. Jurnal Pengabdian Pada Masyarakat; Volume 1, No. 1, Desember 2016: Page 11-17; P-ISSN; 2540-8739 || E-ISSN: 2540-8747.

Dewi, dkk. 2013. Pengembangan Desa Wisata Berbasis Partisipasi Masyarakat Loka di S=Desa Wisata Jatiluwih Tabanan, Bali. Jurnal Kawistara hal: 117-226 Volume 3, No. 2, 17 Agustus 2013.

Haryati, S. 2012. Research and Development (RnD) Sebagai Salah Satu Model Penelitian Dalam Bidang pendidikan. Vol. 37 No. 1, 15 September 2012 : 1126

Ivancevich, J., dkk. 2009. Perilaku dan Manajemen Organisasi Edisi Ketujuh. Jakarta: Erlangga.

Karim, A. 2012. Manajemen Pendidikan Lingkungan Hidup Berbasis Partisipasi. Yogyakarta: Pustaka Ifada.

KLH. 2012. Panduan Adiwiyata 2012. Jakarta: $\mathrm{KLH}$

Sudjana, N. 2010. Pembinaan dan Pengembangan Kurikulum di Sekolah. Bandung: Sinar Baru Algesindo. 
Sugiyono. 2016. Metode Penelitian dan Pengembangan. Bandung: Alfabeta

Suparman, A. 2014. Desain Instruksional Modern. Jakarta: Erlangga

Wiyono, dkk. 2014. Grand Design Model Pembinaan Profesional Guru Berbasis Determinan Kinerja Guru. Jurnal Ilmu Pendidikan, Jilid 20, Nomor 2, Desember 2014, hlm. 165-175. 